\title{
Pelaksanaan asuhan gizi dengan pendekatan terapi gizi medis (TGM) berpengaruh terhadap asupan gizi pasien di RSUD Kota Bekasi
}

\author{
Ika Yuliati C. ${ }^{1}$, I. Made Alit Gunawan ${ }^{2}$, R. Dwi Budiningsari ${ }^{3}$
}

\begin{abstract}
Background: Medical nutrition therapy (MNT) is one of nutrition care models which focuses on integrated patient management involving active participation of doctors, nutritionists, nurses, and other professions within nutrition care team. An indicator of success in nutrition intervention is nutrition intake. Bekasi Municipal Hospital has not implemented integrated nutrition care within a team. The result of monitoring and evaluation during the first quarter of 2006 showed that average patient nutrition intake was only $65-70 \%$ (inadequate).

Objective: To identify the influence of nutrition care implementation using MNT approach to nutrition intake and length of stay at Bekasi Municipal Hospital.

Method: The study was quaci-experimental which used static-group comparison. Samples were patients hospitalized at internal medicine ward of class VIP, 1, 2, and 3. Data obtained consisted of conventional nutrition care and MNT, data of nutrition intake using Comstock visual and 24 hour recall methods. T-test and Mann Whitney statistical test were used to analyze the influence of types of nutrition care to nutrition intake.

Results: Average percentage of total nutrition intake of hospital food and outside hospital food sample with MNT nutrition care was better than conventional nutrition care. Total nutrition intake was $91.71 \%$ for energy, $92.12 \%$ for protein, $111.83 \%$ for fat, and $85.41 \%$ for carbohydrate. The result was significant for energy intake $(p<0.05)$. Nutrition intake of sample hospital was $86.08 \%$ for energy, $88.91 \%$ for protein, $108.55 \%$ for fat, and $78.91 \%$ for carbohydrate. Nutrition intake of outside hospital was $21.94 \%$ for energy, $13.77 \%$ for protein, $12.22 \%$ for fat, and $35.43 \%$ for carbohydrate. They were not significant statistically.

Conclusion: There was difference in nutrition intake between samples with MNT and conventional nutrition care. Nutrition intake of samples with MNT was better than conventional nutrition care and statistically significant $(p<0.05)$.
\end{abstract}

KEY WORDS conventional nutrition care, medical nutrition therapy, nutrition intake

\section{PENDAHULUAN}

Kegiatan pelayanan gizi ruang rawat inap merupakan tindak lanjut dari kegiatan pengadaan makanan dengan tujuan memberikan terapi diet yang sesuai dengan kondisi pasien dalam upaya mempercepat penyembuhan melalui penyediaan makanan, perubahan sikap, dan perilaku terhadap makanan selama perawatan, meningkatkan peran serta masyarakat, dan mencegah kambuhnya penyakit (1).

Makanan yang disediakan di rumah sakit sudah diperhitungkan jumlah maupun mutu gizinya dan harus dihabiskan pasien agar penyembuhannya dapat berjalan sesuai program yang ditetapkan. Asupan gizi yang tidak cukup akan menyebabkan terjadinya penurunan status gizi selama pasien dirawat inap di rumah sakit, berarti pelayanan gizi tidak tercapai. Untuk mengevaluasi mutu pelayanan gizi, salah satunya yaitu dengan mencatat asupan makanan dengan memperhitungkan makanan yang tersisa, karena sisa makanan adalah salah satu indikator keberhasilan pelayanan gizi di ruang rawat inap (2).
Dalam menilai asupan makan pasien yang dirawat di rumah sakit, faktor jenis penyakit sangat perlu diperhatikan karena asupan jenis zat gizi tertentu berkaitan erat dengan suatu jenis penyakit. Hal ini berarti suatu jenis zat gizi spesifik untuk penyakit tertentu.

Kegiatan pelayanan gizi di ruang rawat inap disebut asuhan gizi yang bertujuan untuk memenuhi kebutuhan zat gizi pasien secara optimal. Salah satu pendekatan asuhan gizi yang pada awalnya direkomendasikan oleh The American Diabetes Association (ADA) pada 1994 adalah terapi gizi medis (TGM) atau medical nutrition therapy. Pada beberapa penelitian yang dilaksanakan di Amerika Serikat dan Kanada, konsep TGM telah terbukti berhasil digunakan untuk mengelola penyakit diabetes mellitus, hiperlipidemia, gout, hipertensi, penyakit jantung koroner, gagal ginjal, dan lain-lain (3).

\footnotetext{
1 Instalasi Gizi RSUD Kota Bekasi, JI. Pramuka 55, Bekasi, Jawa Barat

2 Jurusan Gizi Politeknik Kesehatan Departemen Kesehatan RI Yogyakarta, Jl. Tatabumi No. 3 Yogyakarta

3 Magister Gizi Kesehatan UGM, JI Farmako, Sekip Utara, Yogyakarta 55281, e-mail: budiningsari25@yahoo.com
} 
Di Indonesia, penelitian di 33 rumah sakit se-Jabotabek menghasilkan pelaksanaan kegiatan TGM yang belum sepenuhnya dilaksanakan. Umumnya hal ini disebabkan oleh jumlah ahli gizi yang tidak memadai dan kerjasama dengan dokter yang belum berjalan dengan baik (4). Namun evaluasi terhadap pelaksanaan asuhan gizi TGM belum pernah dilakukan, sehingga belum dapat diketahui pengaruhnya terhadap outcome seperti asupan gizi pasien. Hasil evaluasi tersebut sangat diperlukan untuk memberi masukan dan motivasi kepada tenaga gizi maupun pihak manajemen rumah sakit dalam upaya peningkatan pelayanan gizi.

Di Rumah Sakit Umum Daerah (RSUD) Kota Bekasi, saat ini belum dilaksanakan asuhan gizi secara terpadu dalam satu tim. Dalam prosedur tetap pelayanan gizi pasien rawat inap disebutkan bahwa asuhan gizi dilaksanakan dengan menggunakan pendekatan TGM, namun saat ini belum terjadi koordinasi dan komunikasi yang baik antara dokter, perawat, ahli gizi, dan profesi lainnya. Peran ahli gizi dalam hal ini masih sangat sedikit, terutama pada penentuan preskripsi diet. Penentuan diet pasien lebih sering dilakukan oleh dokter tanpa adanya koordinasi dengan ahli gizi. Ahli gizi hanya berperan dalam pemberian intervensi yaitu berupa penyediaan makanan dan konseling gizi.

Dari hasil monitoring dan evaluasi pelayanan gizi rawat inap pada semester I (bulan Januari sampai dengan Juni 2006) di RSUD Kota Bekasi diperoleh rata-rata konsumsi makanan rumah sakit pasien hanya $65-70 \%$. Jumlah ahli gizi yang bertugas di ruang rawat saat ini hanya 6 orang dengan pendidikan D3 Gizi dan pernah mendapat pelatihan TGM. Perbandingan ahli gizi dengan ruang rawat kelas perawatan 1 dan VIP adalah 1:1, sedangkan kelas perawatan 2 dan 3 yaitu 1:2.

Penelitian ini bertujuan untuk mengetahui pengaruh pelaksanaan asuhan gizi dengan pendekatan terapi gizi medis terhadap asupan gizi pasien di RSUD Kota Bekasi.

\section{BAHAN DAN METODE}

Jenis penelitian ini adalah kuasi eksperimen dengan rancangan static-group comparison. Sampel dibagi menjadi dua kelompok. Kelompok pertama diberi perlakuan berupa asuhan gizi TGM dan kelompok kedua diberi asuhan gizi konvensional. Penelitian ini berlangsung mulai bulan September 2006 sampai dengan Januari 2007. Populasi dalam penelitian ini adalah semua pasien baru masuk dan dirawat di RSU Kota Bekasi yang memenuhi kriteria inklusi. Sampel adalah pasien yang dirawat di ruang penyakit dalam kelas perawatan VIP, I, II, dan III yang memenuhi kriteria inklusi komunikatif, kesadaran compos mentis, menderita penyakit degeneratif tanpa komplikasi dengan tingkat keparahan berdasarkan anamnesis medis, dinyatakan sembuh/membaik, dan boleh pulang oleh dokter.

Jumlah sampel dalam penelitian ini dihitung dengan tingkat kepercayaan $95 \%$, kekuatan uji $90 \%$, dan standar deviasi 0,7 sehingga diperlukan sejumlah 46 orang untuk masing-masing kelompok (5). Pemilihan sampel menggunakan cara accidental. Sampel diambil secara berpasangan menurut jenis penyakit, yaitu: DM (diabetes mellitus), CHF (gagal jantung kongestif), SNH (strok nonhemoragik), HT (hipertensi), HHD (penyakit jantung hipertensi) dan menurut kelas perawatan, yaitu: kelas perawatan I dan VIP serta kelas perawatan 2 dan 3 . Instrumen yang digunakan adalah formulir kegiatan TGM, asupan makanan rumah sakit dengan metode visual Comstock, asupan makanan luar rumah sakit dengan metode recall 24 jam, data identitas dan karakteristik responden, serta timbangan makanan. Variabel penelitian terdiri dari variabel bebas yaitu jenis asuhan gizi TGM dan konvensional, serta variabel terikat adalah asupan gizi.

Pengolahan data diawali dengan editing, coding, processing, dan cleaning. Data konsumsi makanan dikonversi dalam bentuk energi, protein, lemak, dan karbohidrat, kemudian dibandingkan dengan kebutuhan sampel. Analisis univariat dilakukan untuk menggambarkan karakteristik sampel dan uji chi square digunakan untuk menguji homogenitas sampel. Analisis bivariat dilakukan untuk melihat adanya pengaruh asuhan gizi TGM terhadap asupan gizi yang menggunakan t-test untuk variabel dengan sebaran data normal dan Mann Whitney untuk variabel dengan sebaran data tidak normal.

\section{HASIL}

\section{Karakteristik sampel}

Selama penelitian diperoleh 46 orang sampel untuk masing-masing kelompok, sehingga jumlah sampel secara keseluruhan adalah 92 orang. Karakteristik sampel dapat dilihat pada Tabel 1. Jenis kelamin sampel, baik yang diberi asuhan gizi konvensional maupun TGM terbanyak adalah perempuan, masing-masing sebesar $60,87 \%$ dan $56,52 \%$, sedangkan pendidikan sampel terbanyak adalah tidak tamat SD masing-masing sebesar $54,35 \%$ dan $63,04 \%$. Sebagian besar sampel yang diberi asuhan gizi konvensional dan TGM bekerja di sektor swasta, masing-masing sebesar $67,39 \%$ dan $69,57 \%$. Umur sampel pada kedua kelompok terbanyak berkisar antara 41-60 tahun dengan persentase masingmasing sebesar $65,22 \%$. Status gizi awal (IMT) terbanyak adalah normal, sebanyak $67,39 \%$ untuk sampel dengan asuhan gizi konvensional dan $80,43 \%$ untuk sampel dengan asuhan gizi TGM. Hasil uji chi square menunjukkan tidak 
TABEL 1. Karakteristik sampel penelitian

\begin{tabular}{|c|c|c|c|c|c|c|c|c|}
\hline \multirow{3}{*}{ Karakteristik } & \multicolumn{4}{|c|}{ Jenis asuhan gizi } & \multirow{2}{*}{\multicolumn{2}{|c|}{ Total }} & \multirow{3}{*}{$\chi^{2}$} & \multirow{3}{*}{$\mathbf{p}$} \\
\hline & \multicolumn{2}{|c|}{ Konvensional } & \multicolumn{2}{|c|}{ Terapi gizi medis } & & & & \\
\hline & $\mathbf{n}$ & $\%$ & $\mathbf{n}$ & $\%$ & $\mathbf{n}$ & $\%$ & & \\
\hline \multicolumn{9}{|l|}{ Jenis kelamin } \\
\hline Laki-laki & 18 & 39,13 & 20 & 43,48 & 38 & 41,30 & 0,045 & 0,832 \\
\hline Perempuan & 28 & 60,87 & 26 & 56,52 & 54 & 58,70 & & \\
\hline \multicolumn{9}{|l|}{ Tingkat pendidikan } \\
\hline Rendah & 25 & 54,35 & 29 & 63,04 & 54 & 58,70 & 0,767 & 0,682 \\
\hline Menengah & 19 & 41,30 & 15 & 32,61 & 34 & 36,96 & & \\
\hline Tinggi & 2 & 4,35 & 2 & 4,35 & 4 & 4,34 & & \\
\hline \multicolumn{9}{|l|}{ Pekerjaan } \\
\hline PNS & 15 & 32,61 & 13 & 28,26 & 28 & 30,43 & 1,034 & 0,596 \\
\hline Swasta & 31 & 67,39 & 32 & 69,57 & 63 & 68,48 & & \\
\hline Pelajar & & 0 & 1 & 2,17 & 1 & 1,09 & & \\
\hline \multicolumn{9}{|l|}{ Umur } \\
\hline$\leq 40$ th & 5 & 10,87 & 4 & 8,70 & 9 & 9,78 & 0,155 & 0,926 \\
\hline$\overline{4} 1-60$ th & 30 & 65,22 & 30 & 65,22 & 60 & 65,22 & & \\
\hline$\geq 61$ th & 11 & 23,91 & 12 & 26,08 & 23 & 25,00 & & \\
\hline \multicolumn{9}{|l|}{ Status gizi awal (IMT) } \\
\hline Kurus & 2 & 4,35 & 1 & 2,18 & 3 & 3,26 & 2,053 & 0,358 \\
\hline Normal & 31 & 67,39 & 37 & 80,43 & 68 & 73,91 & & \\
\hline Gemuk & 13 & 28,26 & 8 & 17,39 & 21 & 22,83 & & \\
\hline
\end{tabular}

terdapat perbedaan proporsi karakteristik sampel, baik dari jenis kelamin, tingkat pendidikan, pekerjaan, umur, maupun status gizi awal (IMT).

\section{Pengaruh asuhan gizi terhadap asupan gizi}

Hasil analisis asupan gizi seluruh sampel (92 orang) menunjukkan bahwa ada perbedaan rata-rata persentase asupan gizi total, rumah sakit, dan luar rumah sakit, baik untuk energi, protein, lemak, maupun karbohidrat antara sampel dengan asuhan gizi konvensional dan sampel dengan asuhan gizi TGM.

Rata-rata persentase asupan gizi total dan rumah sakit sampel dengan asuhan gizi konvensional dan TGM dikatakan baik, karena asupan gizi mencapai $\geq 80 \%$ dari kebutuhan untuk energi, protein, dan karbohidrat, tetapi asupan lemak dikatakan kurang baik karena asupannya mencapai $>100 \%$. Uji statistik yang dilakukan menunjukkan hasil yang bermakna pada perbedaan asupan energi total serta asupan energi, lemak, dan karbohidrat makanan dari rumah sakit $(p<0,05)$. Ratarata persentase asupan luar rumah sakit untuk energi dan karbohidrat termasuk kategori kurang karena lebih dari $20 \%$. Uji statistik membuktikan bahwa tidak satu pun rata-rata asupan gizi luar rumah sakit menunjukkan hasil yang bermakna $(p>0,05)$ (Tabel 2).

\section{Asupan gizi menurut kategori jenis penyakit}

Dari 52 sampel dengan penyakit DM, terdapat 15 sampel yang mengkonsumsi makanan dari luar rumah sakit. Rata-rata persentase asupan gizi total dan rumah sakit untuk semua zat gizi pada asuhan gizi TGM dikatakan baik, karena asupannya lebih dari $80 \%$ dan nilainya lebih besar dibanding pada asuhan gizi konvensional. Berdasarkan uji statistik, perbedaan tersebut hanya bermakna pada asupan energi dan karbohidrat makanan rumah sakit $(p<0,05)$, sedangkan hasil uji statistik ratarata persentase asupan gizi makanan luar rumah sakit tidak menunjukkan hasil bermakna pada semua zat gizi $(p>0,05)$ (Tabel 3).

Sampel dengan penyakit CHF sebanyak 16 orang dan yang mengkonsumsi makanan luar rumah sakit sebanyak 4 sampel. Untuk semua zat gizi, rata-rata asupan gizi total dan rumah sakit lebih besar pada asuhan gizi TGM dibanding konvensional, namun perbedaan tersebut tidak bermakna secara statistik $(p>0,05)$. Rata-rata persentase asupan luar rumah sakit lebih kecil dan lebih baik pada sampel dengan asuhan gizi konvensional (<20\%).

Dari 14 sampel dengan penyakit $\mathrm{SNH}$, sebanyak 5 sampel yang mengkonsumsi makanan dari luar rumah sakit. Rata-rata persentase asupan total sampel dengan penyakit SNH untuk semua jenis zat gizi lebih besar pada asuhan gizi konvensional dibandingkan dengan asuhan gizi TGM dan rata-rata tersebut termasuk dalam kategori baik $(\geq 80 \%)$. Untuk asupan rumah sakit, sampel dengan asuhan gizi TGM asupannya lebih besar daripada konvensional, namun hal ini perlu diwaspadai karena asupan lemak lebih dari $100 \%$. Uji statistik yang dilakukan menunjukkan hasil yang tidak bermakna pada asupan semua jenis zat gizi $(p>0,05)$. Rata-rata persentase asupan luar rumah sakit sampel dengan asuhan gizi TGM 
TABEL 2. Rata-rata persentase asupan gizi total, rumah sakit, dan luar rumah sakit sehari sampel berdasarkan jenis asuhan gizi

\begin{tabular}{cccc}
\hline \multirow{2}{*}{ Asupan gizi } & \multicolumn{2}{c}{ Jenis asuhan gizi } & \\
\cline { 2 - 3 } & Konvensional & Terapi gizi medis & p \\
\cline { 2 - 3 } & Mean \pm SD & Mean \pm SD & \\
\hline Total & $(\mathrm{n}=46)$ & $(\mathrm{n}=46)$ & \\
Energi (\%) & $82,53 \pm 21,92$ & $91,71 \pm 24,90$ & $0,047^{*}$ \\
Protein (\%) & $87,82 \pm 27,26$ & $92,12 \pm 24,41$ & 0,190 \\
Lemak (\%) & $105,59 \pm 29,96$ & $111,83 \pm 26,47$ & 0,172 \\
Karbohidrat (\%) & $83,92 \pm 36,16$ & $85,41 \pm 36,64$ & 0,299 \\
Rumah sakit & $(\mathrm{n}=46)$ & $(\mathrm{n}=46)$ & \\
Energi (\%) & $76,52 \pm 18,79$ & $86,08 \pm 18,27$ & $0,015^{*}$ \\
Protein (\%) & $81,93 \pm 22,87$ & $88,91 \pm 20,46$ & 0,143 \\
Lemak (\%) & $98,06 \pm 23,07$ & $108,55 \pm 24,41$ & $0,037^{\star}$ \\
Karbohidrat (\%) & $70,62 \pm 19,22$ & $78,91 \pm 18,97$ & $0,040^{*}$ \\
Luar rumah sakit & $(\mathrm{n}=16)$ & $(\mathrm{n}=12)$ & \\
Energi (\%) & $17,97 \pm 11,50$ & $21,94 \pm 18,32$ & 0,487 \\
Protein (\%) & $13,80 \pm 3,86$ & $13,77 \pm 3,70$ & 0,996 \\
Lemak (\%) & $17,95 \pm 6,27$ & $12,22 \pm 2,80$ & 0,461 \\
Karbohidrat (\%) & $37,34 \pm 9,05$ & $35,43 \pm 11,34$ & 0,895 \\
\hline Keter & & & \\
\hline
\end{tabular}

Keterangan:

* Bermakna $(p<0,05)$

lebih kecil daripada konvensional dan termasuk dalam kategori baik $(\leq 20 \%)$, kecuali asupan karbohidrat yang masih di atas $20 \%$.

Sampel dengan penyakit HT sebanyak 6 orang dan yang mengkonsumsi makanan dari luar rumah sakit hanya 3 orang. Rata-rata persentase asupan gizi total dan rumah sakit sampel dengan penyakit HT pada asuhan gizi konvensional termasuk kategori baik ( $\geq 80 \%$ ) untuk semua jenis zat gizi, namun rata-rata tersebut tidak lebih besar dibandingkan pada asuhan gizi TGM. Rata-rata persentase asupan gizi sampel pada asuhan gizi TGM yang lebih besar tersebut dikatakan kurang baik, karena asupan semua zat gizi lebih dari $100 \%$. Untuk rata-rata persentase asupan gizi luar rumah sakit, sampel pada asuhan gizi konvensional asupannya lebih baik daripada asuhan gizi TGM.

Dari 4 sampel dengan penyakit HHD, hanya 1 sampel yang mengkonsumsi makanan luar rumah sakit. Rata-rata persentase asupan gizi total dan rumah sakit lebih besar pada sampel dengan asuhan gizi konvensional daripada asuhan gizi TGM. Pada asuhan gizi TGM, asupan gizi total

TABEL 3. Rata-rata persentase asupan gizi total, rumah sakit, dan luar rumah sakit sehari sampel berdasarkan jenis asuhan gizi pada penyakit DM

\begin{tabular}{cccc}
\hline & \multicolumn{2}{c}{ Jenis asuhan gizi } & \\
\cline { 2 - 3 } Asupan gizi & Konvensional & Terapi gizi medis & p \\
\cline { 2 - 3 } & Mean \pm SD & Mean \pm SD & \\
\hline Total & $(\mathrm{n}=26)$ & $(\mathrm{n}=26)$ & \\
Energi (\%) & $81,19 \pm 24,35$ & $87,71 \pm 16,40$ & 0,263 \\
Protein (\%) & $84,04 \pm 27,02$ & $88,14 \pm 17,62$ & 0,521 \\
Lemak (\%) & $100,77 \pm 26,56$ & $105,94 \pm 20,96$ & 0,534 \\
Karbohidrat (\%) & $82,27 \pm 34,91$ & $82,89 \pm 17,44$ & 0,798 \\
Rumah sakit & $(\mathrm{n}=26)$ & $(\mathrm{n}=26)$ & \\
Energi (\%) & $73,84 \pm 19,90$ & $84,45 \pm 15,33$ & $0,036^{*}$ \\
Protein (\%) & $78,38 \pm 23,20$ & $86,05 \pm 17,47$ & 0,185 \\
Lemak (\%) & $94,07 \pm 23,28$ & $103,66 \pm 20,56$ & 0,122 \\
Karbohidrat (\%) & $68,15 \pm 19,32$ & $79,93 \pm 17,62$ & $0,026^{*}$ \\
Luar rumah sakit & $(\mathrm{n}=10)$ & $(\mathrm{n}=5)$ & \\
Energi (\%) & $19,53 \pm 13,32$ & $16,78 \pm 10,11$ & 0,692 \\
Protein (\%) & $11,40 \pm 10,63$ & $10,78 \pm 6,61$ & 0,907 \\
Lemak (\%) & $13,54 \pm 10,60$ & $11,80 \pm 8,92$ & 0,759 \\
Karbohidrat (\%) & $38,06 \pm 12,56$ & $15,16 \pm 7,20$ & 0,231 \\
\hline Ket & & & \\
\hline
\end{tabular}

Keterangan:

* Bermakna $(p<0,05)$ 
TABEL 4. Rata-rata persentase asupan gizi total, rumah sakit, dan luar rumah sakit sehari sampel berdasarkan jenis asuhan gizi pada kelas perawatan 2 dan 3

\begin{tabular}{cccc}
\hline & \multicolumn{2}{c}{ Jenis asuhan gizi } & \\
\cline { 2 - 3 } Asupan gizi & Konvensional & Terapi gizi medis & p \\
\cline { 2 - 3 } & Mean \pm SD & Mean \pm SD & \\
\hline Total & $(\mathrm{n}=26)$ & $(\mathrm{n}=26)$ & \\
Energi (\%) & $75,39 \pm 13,98$ & $92,33 \pm 23,24$ & $0,002^{*}$ \\
Protein (\%) & $74,99 \pm 14,24$ & $90,45 \pm 24,00$ & $0,006^{*}$ \\
Lemak (\%) & $96,29 \pm 18,29$ & $113,19 \pm 25,44$ & $0,007^{*}$ \\
Karbohidrat (\%) & $74,12 \pm 27,41$ & $84,51 \pm 36,99$ & 0,246 \\
Rumah sakit & $(\mathrm{n}=26)$ & $(\mathrm{n}=26)$ & \\
Energi (\%) & $71,29 \pm 14,28$ & $85,12 \pm 16,52$ & $0,002^{*}$ \\
Protein (\%) & $72,99 \pm 14,91$ & $85,89 \pm 18,21$ & $0,006^{*}$ \\
Lemak (\%) & $92,81 \pm 18,39$ & $108,88 \pm 23,63$ & $0,012^{*}$ \\
Karbohidrat (\%) & $64,14 \pm 13,90$ & $78,48 \pm 18,45$ & $0,002^{*}$ \\
Luar rumah sakit & $(\mathrm{n}=8)$ & $(\mathrm{n}=7)$ & \\
Energi (\%) & $14,40 \pm 12,45$ & $22,75 \pm 17,01$ & 0,294 \\
Protein (\%) & $6,71 \pm 5,84$ & $13,61 \pm 12,41$ & 0,182 \\
Lemak (\%) & $7,62 \pm 6,20$ & $11,00 \pm 7,77$ & 0,366 \\
Karbohidrat (\%) & $33,85 \pm 15,72$ & $34,66 \pm 38,19$ & 0,971 \\
\hline Keterangan: & & &
\end{tabular}

Keterangan:

*Bermakna $(p<0,05)$

dan rumah sakit tersebut termasuk dalam kategori kurang $(<80 \%)$, sedangkan rata-rata persentase asupan luar rumah sakit sampel termasuk dalam kategori baik ( $<20 \%)$.

\section{Asupan gizi menurut kategori kelas perawatan}

Dari 52 sampel kelas perawatan 2 dan 3, sebanyak 15 sampel mengkonsumsi makanan dari luar rumah sakit. Pada sampel kelas perawatan 2 dan 3, rata-rata persentase asupan gizi total dan rumah sakit lebih baik pada sampel dengan asuhan gizi TGM untuk semua jenis zat gizi dibandingkan dengan asuhan gizi konvensional. Setelah dilakukan uji statistik antara kedua asuhan gizi, terdapat perbedaan bermakna pada semua zat gizi, baik untuk asupan gizi total (energi, protein, dan lemak) maupun asupan rumah sakit $(p<0,05)$. Rata-rata persentase asupan gizi luar rumah sakit lebih baik pada sampel dengan asuhan gizi konvensional dibandingkan dengan asuhan gizi TGM, walaupun rata-rata asupan karbohidrat masih di atas $20 \%$. Uji statistik rata-rata persentase asupan gizi luar rumah sakit antara kedua asuhan gizi menunjukkan hasil yang tidak bermakna ( $p>0,05)$ (Tabel 4).

Jumlah sampel kelas perawatan 1 dan VIP adalah 38 orang dan 13 sampel di antaranya mengkonsumsi makanan dari luar rumah sakit. Rata-rata persentase asupan gizi total dan rumah sakit sampel kelas perawatan VIP dan I termasuk dalam kategori baik $(\geq 80 \%)$ pada kedua jenis asuhan gizi untuk semua zat gizi. Rata-rata persentase tersebut nilainya lebih kecil pada asuhan gizi TGM daripada asuhan gizi konvensional dan hasil menunjukkan tidak bermakna $(p>0,05)$ untuk semua jenis zat gizi. Rata-rata persentase asupan gizi luar rumah sakit lebih baik pada sampel dengan asuhan gizi TGM dibandingkan dengan asuhan gizi konvensional, namun perbedaan tersebut tidak bermakna secara statistik $(p>0,05)$.

\section{BAHASAN}

Hasil analisis terhadap sampel secara keseluruhan (Tabel 2) menunjukkan perbedaan bermakna secara statistik $(p<0,05)$ pada rata-rata persentase asupan gizi total dan rumah sakit antara sampel dengan asuhan gizi konvensional dan asuhan gizi TGM. Sampel dengan asuhan gizi TGM asupan gizinya lebih baik untuk semua zat gizi (energi, protein, lemak, dan karbohidrat) dibandingkan dengan asuhan gizi konvensional.

Lebih besarnya asupan gizi sampel dengan TGM dibanding konvensional ini disebabkan oleh perlakuan yang berbeda. Pada asuhan gizi TGM, ahli gizi aktif melakukan koordinasi dengan dokter, perawat, dan farmasi mulai tahap perencanaan, intervensi berupa pemberian diet, konseling, sampai dengan monitoring diet, sedangkan pada asuhan gizi konvensional ahli gizi bekerja sendiri, tidak turut aktif pada kegiatan visite bersama, dan pemberian makanan berdasarkan stándar diet rumah sakit. Intervensi pada asuhan gizi TGM berupa pemberian makanan dihitung secara individual dan kegiatan visite bersama digunakan untuk memberi masukan tentang hasil evaluasi diet oleh ahli gizi kepada seluruh anggota tim, sehingga bila terjadi masalah segera dapat dipecahkan bersama.

Hal ini sesuai dengan hasil penelitian di rumah sakit di Argentina yang menyatakan bahwa adanya intervensi yang tepat (dalam hal ini intervensi gizi) akan menyebabkan 
peningkatan indikator klinis seperti asupan gizi yang meningkat (6). Besarnya asupan gizi makanan rumah sakit merupakan salah satu indikator keberhasilan intervensi gizi yang diberikan (2). Hal yang perlu diperhatikan dalam pelaksanaan asuhan gizi adalah peran aktif dan kerjasama dari masing-masing anggota, karena hal ini dapat dikatakan sebagai syarat utama kesuksesan misi tim asuhan gizi (7).

Hasil penelitian terhadap asupan gizi luar rumah sakit menunjukkan bahwa asupan protein dan lemak luar rumah sakit pada asuhan gizi TGM termasuk dalam kategori baik $(\leq 20 \%)$, tetapi asupan energi dan karbohidrat masih kurang $(>20 \%$ ). Hasil uji statistik (Tabel 2) menunjukkan bahwa perbedaan tersebut tidak bermakna, artinya asuhan gizi TGM tidak berpengaruh pada asupan gizi luar rumah sakit. Dengan demikian, pada asuhan gizi TGM masih perlu ditingkatkan pemberian motivasi agar pasien hanya mengkonsumsi makanan dari rumah sakit saja melalui kegiatan konseling. Di samping itu, perlu dilakukan penilaian terhadap cita rasa makanan rumah sakit dan jadwal pemberian makan agar waktu tunggu makan pasien tidak terlalu lama (8).

\section{Asupan gizi menurut kategori jenis penyakit}

Penelitian pada penyakit DM menunjukkan hasil yang bermakna pada asupan gizi rumah sakit untuk energi dan karbohidrat. Hal ini membuktikan bahwa asuhan gizi TGM yang dilakukan sudah cukup baik, sehingga menyebabkan asupan gizi sampel dengan penyakit DM sudah sesuai dengan prinsip dietnya. Namun demikian, asupan lemak yang tinggi perlu diwaspadai karena dapat meningkatkan risiko terjadinya komplikasi. Diet rendah lemak dan tinggi karbohidrat akan menghasilkan perbaikan pada toleransi glukosa (9).

Untuk penyakit lain ( $\mathrm{CHF}, \mathrm{SNH}, \mathrm{HT}$, dan $\mathrm{HHD}$ ), asuhan gizi TGM tidak berpengaruh terhadap asupan gizi. Pada semua jenis penyakit, rata-rata persentase asupan lemak termasuk dalam kategori kurang baik (100\%). Hal ini mungkin disebabkan oleh adanya pembatasan pemberian natrium pada diet yang diberikan yang akan berpengaruh terhadap cita rasa makanan. Dengan demikian, asuhan gizi TGM perlu dilaksanakan lebih optimal untuk mengusahakan agar asupan gizi menjadi lebih baik dengan meningkatkan pemberian motivasi pada pasien untuk menghabiskan makanannya dengan memberikan pemahaman bahwa diet merupakan bagian dari terapi penyembuhan penyakit. Di samping itu, asupan lemak yang tinggi juga bertentangan dengan prinsip diet penyakit jantung dan pembuluh darah (10).

Adanya asupan lemak yang tinggi pada sampel dari tiap jenis penyakit harus menjadi perhatian, bukan hanya bagi anggota tim asuhan gizi, tetapi seluruh komponen yang terlibat dalam sistem pelayanan gizi. Hal ini dikarenakan kurang seimbangnya komposisi zat gizi dari menu yang disajikan. Penelitian pada rumah sakit di Denmark mendukung hal tersebut dan menyatakan bahwa salah satu hambatan pada pelaksanaan terapi gizi adalah kurangnya kualitas dan pilihan menu (11).

\section{Asupan gizi berdasarkan kategori kelas perawatan}

Pada kelas perawatan 1 dan VIP, rata-rata persentase asupan gizi total dan rumah sakit untuk semua jenis zat gizi relatif tidak berbeda antara sampel pada asuhan gizi konvensional dan TGM. Uji statistik tidak menunjukkan hasil yang bermakna. Hal ini mungkin disebabkan menu yang disajikan pada kelas perawatan 1 dan VIP sudah memenuhi selera pasien. Hal ini terbukti dari bukan hanya sampel dengan asuhan gizi TGM saja yang asupan gizinya baik, sampel dengan asuhan gizi konvensional juga asupan gizinya sudah baik ( $\geq 80 \%)$. Suatu penelitian di rumah sakit mendukung hal tersebut, yaitu kepuasan pasien kelas perawatan VIP atas makanan yang disajikan relatif lebih besar dibandingkan dengan pasien yang dirawat pada kelas perawatan di bawahnya (12).

Dari segi kualitas, menu yang disajikan kepada sampel kelas perawatan 2 dan 3 dikatakan kurang, namun dengan adanya asuhan gizi TGM, sampel dapat menghabiskan makanan yang disajikan lebih banyak. Hal ini disebabkan oleh penanganan pasien yang dilakukan secara terpadu oleh tim dan koordinasi di antara anggota (disiplin ilmu) yang dilakukan dengan baik, sehingga masalah pada pasien dapat segera diketahui penyebab dan solusinya, terutama saat dilaksanakan visite bersama dan pertemuan mingguan anggota tim asuhan gizi.

Sejalan dengan penelitian ini, suatu penelitian mengenai intervensi asuhan gizi pada pasien rawat inap di rumah sakit di Denmark menghasilkan peningkatan pada persentase asupan energi dan protein sebelum dan setelah intervensi, yaitu dari $72 \%$ menjadi $85 \%$ untuk protein dan $85 \%$ menjadi $103 \%$ untuk energi (13).

Secara keseluruhan, asupan gizi yang berbeda pada asuhan gizi konvensional dan TGM tersebut disebabkan pengelolaan pasien rawat inap yang dilakukan secara menyeluruh dengan memperhatikan setiap perubahan pada pasien secara individual. Pengelolaan pasien dilakukan oleh tim asuhan gizi yang setiap anggotanya berperan aktif memberikan informasi mengenai evaluasi terhadap kondisi pasien dari beberapa disiplin ilmu, seperti: medis, perawatan, gizi, dan farmasi yang dilakukan pada saat visite bersama setiap hari dan pada pertemuan mingguan di ruang rawat masing-masing.

Hal yang perlu diperhatikan dalam pelaksanaan asuhan gizi adalah peran aktif dan kerjasama dari masingmasing anggota. Hal ini dapat dikatakan menjadi syarat utama kesukesan misi tim asuhan gizi. Pada pelaksanaan asuhan gizi, diperlukan pengetahuan dan keahlian khusus dalam bidang gizi, karena proses pemberian diet pada 
pasien, penilaian status gizi, menyusun rencana, dan menentukan diet yang akan diberikan, mencatat kemampuan toleransi, dan komplikasi yang timbal, serta menentukan bila diet harus diakhiri atau dialihkan dalam bentuk lain merupakan proses yang kompleks sehingga diperlukan pelatihan secara terus-menerus (7).

Suatu penelitian di rumah sakit di Denmark mendapatkan hasil bahwa hambatan pada pemberian diet di antaranya: masalah gizi masih merupakan prioritas yang rendah, tidak ada prosedur tetap, kurangnya pengetahuan, kurangnya kualitas dan pilihan menu serta kurangnya dukungan dari manajer rumah sakit (13).

Penelitian lain yang juga berlokasi di rumah sakit di Denmark mendapatkan hasil bahwa prospek perbaikan pelayanan gizi akan meningkat apabila melakukan hal-hal seperti berikut ini, antara lain: manajemen rumah sakit menetapkan hal tersebut sebagai prioritas utama, masing-masing profesi mempunyai waktu yang cukup, monitor dan evaluasi dijalankan terhadap alur makanan keseluruhan dari dapur ke pasien di tingkat penyelenggara makanan, sedangkan pada tingkat pasien perbaikan pelayanan gizi akan meningkat jika akses dialog dengan petugas ruang rawat berlangsung dengan baik dan pasien dapat menerima informasi mengenai pilihan makanan dan minuman (14).

\section{KESIMPULAN DAN SARAN}

Secara keseluruhan, rata-rata asupan gizi sampel seharí dengan asuhan gizi TGM lebih baik dibandingkan sampel dengan asuhan gizi konvensional dan hal ini bermakna secara statistik. Berdasarkan kategori jenis penyakit dan kelas perawatan, hanya rata-rata asupan sampel dengan penyakit DM serta sampel pada kelas perawatan 2 dan 3 yang menunjukkan hasil bermakna.

Saran yang dapat diberikan adalah asuhan gizi dengan pendekatan TGM perlu dilaksanakan di RSUD Kota Bekasi sebagai upaya meningkatkan mutu pelayanan gizi, khususnya pelayanan pasien rawat inap. Agar dapat dilakukan secara optimal, sebaiknya dilakukan perbaikan untuk mengatasi beberapa kekurangan yang ditemui pada pelaksanaan TGM, antara lain reorganisasi tim asuhan gizi pada komponen sistem asuhan gizi secara keseluruhan dan

\section{RUJUKAN}

1. Departemen Kesehatan RI. Buku Pedoman Pelayanan Gizi Rumah Sakit. Jakarta: Departemen Kesehatan RI; 1991.

2. Departemen Kesehatan RI. Pedoman Pelayanan Gizi Rumah Sakit. Jakarta: Departemen Kesehatan RI; 2003.

3. Indrarti M. Terapi Gizi Medis sebagai Model dalam Asuhan Gizi. Naskah Lengkap Short Course Asuhan peningkatan mutu sumber daya manusia (SDM), baik dengan cara kursus penyegar asuhan gizi TGM maupun kursus pengembangan menu bagi penyakit tertentu. Hal ini dilakukan sebagai upaya untuk meningkatkan kemampuan dalam mengelola asuhan gizi pasien dengan berbagai penyakit (tidak hanya DM) serta meningkatkan mutu makanan pasien yang saat ini masih tinggi pada kandungan lemak.

Pada komponen proses, perlu dilakukan peningkatan terhadap kegiatan intervensi pada TGM berupa pemberian diet dan konseling gizi agar dapat meminimalkan asupan gizi luar rumah sakit dengan cara: meningkatkan pemberian motivasi kepada pasien agar dapat memahami pentingnya terapi diet bagi kesembuhan penyakit, meningkatkan koordinasi dengan bagian produksi makanan untuk meningkatkan kualitas menu, meninjau kembali jadwal pemberian makan agar tidak terjadi jarak waktu makan yang terlalu dekat atau jauh, dan meningkatkan kegiatan monev agar pasien dengan kondisi tertentu cepat ditangani, misalnya adanya makanan pengganti untuk makanan pantangan.

Di samping itu, perlu dilakukan pula peninjauan kembali prosedur tetap pelayanan gizi rawat inap yang sudah ada. Dengan mempertimbangkan terbatasnya jumlah SDM (ahli gizi) yang ada saat ini, sebagai langkah awal kegiatan TGM diprioritaskan untuk pasien pada kelas perawatan 1 dan VIP dan untuk pasien yang memerlukan diet khusus pada kelas perawatan 2 dan 3 .

Untuk penelitian selanjutnya disarankan untuk dilakukan penelitian terhadap pelaksanaan TGM pada penyakit lain dengan menganalisis faktor-faktor lain yang mempengaruhi asupan gizi dan lama rawat inap, seperti: kualitas menu, jenis terapi dan tingkat keparahan penyakit.

\section{Ucapan terima kasih}

Penulis mengucapkan terima kasih kepada Direktur RSUD Kota Bekasi atas ijin yang telah diberikan untuk melakukan penelitian di RSUD Kota Bekasi, kepada para petugas pengumpul data, serta semua pihak atas segala dukungan dan bantuan yang telah diberikan sejak persiapan sampai dengan pengumpulan data. Ucapan terima kasih juga disampaikan kepada seluruh pasien yang telah bersedia menjadi sampel pada penelitian ini.

Gizi Rumah Sakit Program Studi IKM FK-UGM; 31 Maret-2 April 2005; Yogyakarta, Indonesia.

4. Waspadji S. Dietetik dan Pelayanan Medis: Tantangan dan Wacana Mutakhir dalam Menghadapi Era Globalisasi. Dalam: Persagi. Prosiding Konas Persagi; 2002; Jakarta, Indonesia.

5. Lemeshow S, Hosmer D, Klar J. 1990. Adequacy of Sample Size in Health Studies. (Terjemahan) Pramono D. Yogyakarta: UGM Press; 1997. 
6. Wyszynski D, Crivelli A, Esquerro S, Rodrigues A. Assessment of Nutritional Status in A Population of Recently Hospitalized Patients. Medicina 1997;58:51-7.

7. Dinarto M. Tim Nutrisi. Majalah Gizi Medik Indonesia 2002;1(1):7-9.

8. Mukrie AN. Manajemen Pelayanan Institusi Dasar. Jakarta: Departemen Kesehatan RI; 1990.

9. Franz MJ. Medical Nutrition Therapy for Diabetes Mellitus and Hypoglycemia of Nondiabetic Origin: Krause's Food, Nutrition, \& Diet Therapy. USA: Elsevier; 2004.

10. Morgan SL, Newton LE. Therapeutic Diets: Handbook of Clinical Nutrition. Philadelphia: Mosby Inc; 2006.
11. Rasmussen $\mathrm{H}$, Kondrup J, Staun M, Ladefoged K, Lindorff K, Jorgensen L, et al. A Method for Implementation of Nutritional Therapy in Hospitals. Clin Nutr 2006;25(3):515-23.

12. Almatsier S. Pelayanan Gizi Rumah Sakit dan Perkembangan Ilmu serta Teknologi. Gizi Indonesia 1992;XVIII(1-2):97-104.

13. Lassen KO, Kruse F, Bjerrum M, Jensen L, Hermansen K. Nutritional Care of Danish Medical Inpatiens: Effect on Dietary Intake and The Occupational Groups Perspectives of Intervention. Nutr J 2004;3:1-13.

14. Lassen KO, Olsen J, Griderslev E, Kruse F, Bjerrum M. Nutritional Care of Medical Inpatient: A Health Technology Assessment. BMC 2006;6(7):1-12. 